\title{
Influence of invasive Acer negundo leaf litter on benthic microbial abundance and activity in the littoral zone of a temperate river in Lithuania
}

\author{
Alina Krevš and Alè Kučinskiené* \\ Nature Research Centre, Institute of Botany, Zaliuju ezeru 49, Vilnius LT-08648, Lithuania
}

\begin{abstract}
Riparian forests are known as important source of allochthonous organic matter entering to water ecosystems via fallen leaves. However, leaf litter, depending on their quality, may create different conditions for benthic microorganisms functioning in littoral zone of water bodies. In order to evaluate the impact of riparian invasive Acer negundo on littoral water zone of the River Neris (Lithuania), we performed physicochemical and microbiological investigations in bottom sediments of three different sites of the river. One sampling site was close by riparian A. negundo, another close by native Alnus glutinosa location and a third zone was near the shore without riparian vegetation. Content of nutrients in the littoral sediments differed between invasive and native trees leaf litter accumulation sites, while not always significantly. The highest microbial densities as well as benthic community respiratory activity (expressed as the rate of organic carbon mineralization) occurred in A. negundo leaves accumulation site. In sediments of this site, the most intensive anaerobic terminal organic carbon mineralization process - sulfate reduction and the highest concentration of hydrogen sulfide were also observed. Differences in the intensity of mineralization processes between sites suggest that the replacement of the riparian native species such as dominant $A$. glutinosa by invasive $A$. negundo with higher biodegradability leaves may induce local changes in organic matter processing in the littoral zone of the river. The increase of littoral bioproductivity in the accumulation zone of A. negundo leaf litter can occur due to the inflow of available organic matter and its intensive mineralization.
\end{abstract}

Keywords: leaf litter / benthic microorganisms / river

Résumé - Influence de la litière d'Acer negundo invasif sur l'abondance et l'activité microbienne benthique dans la zone littorale d'une rivière en Lituanie. Les forêts riveraines sont connues comme source importante de matière organique allochtone entrant dans les écosystèmes aquatiques via les feuilles tombées. Cependant, la litière, en fonction de sa qualité, peut créer différentes conditions pour que les microorganismes benthiques fonctionnent dans la zone littorale des masses d'eau. Afin d'évaluer l'impact de l'Acer negundo invasif dans la zone d'eau littorale de la rivière Neris (Lituanie), nous avons procédé à des recherches physico-chimiques et microbiologiques dans les sédiments de trois sites différents de la rivière. Un site d'échantillonnage était proche de A. negundo riverain, un autre proche de l'emplacement d'Alnus glutinosa indigène et une troisième zone était près d'une rive sans végétation riveraine. Les contenus en nutriments dans les sédiments du littoral différaient entre les sites d'accumulation de déchets de feuilles d'arbres envahissants et natifs, bien qu'ils ne soient pas toujours significativement différents. Les densités microbiennes les plus élevées ainsi que l'activité respiratoire de la communauté benthique (exprimée en taux de minéralisation du carbone organique) sont observées dans le site d'accumulation de feuilles d'A. negundo. Dans les sédiments de ce site, on a observé le processus de minéralisation du carbone organique anaérobie la plus intensive - la réduction des sulfates et la plus forte concentration de sulfure d'hydrogène. Les différences dans l'intensité des processus de minéralisation entre les sites suggèrent que le remplacement des espèces indigènes riveraines telles que $A$. glutinosa dominante par une invasive $A$. negundo avec des feuilles de biodégradabilité plus élevées peut induire des changements locaux dans le

\footnotetext{
* Corresponding author: ale.kucinskiene@gmail.com
} 
traitement de la matière organique dans la zone littorale de la rivière. L'augmentation de la bioproductivité du littoral dans la zone d'accumulation de la litière d'A. negundo peut se produire en raison de l'afflux de matière organique disponible et de sa minéralisation intensive.

Mots clés : litière / microorganismes benthiques / rivière

\section{Introduction}

Riparian forest strips play an important role in regulating anthropogenic nutrient transport into water body (Weissteiner et al., 2013). Although riparian vegetation acts as a filter reducing input from surroundings, it subsidizes aquatic systems with organic matter (Graça and Canhoto, 2006) and may have a negative impact due to the acceleration of littoral bioproductivity. Leaf litter is one of the most important sources of nutrients and energy supporting food webs in oligotrophic systems and small forested streams (Wallace et al., 1997) and may also be important point sources of nutrients inducing siltation processes in the littoral zone of larger water bodies. Leaf litter processing has been studied extensively in forests and forested streams, particularly small ones (Fargen et al., 2015), but received scant attention in littoral zones of rivers or lakes. Large rivers and streams may differ in some traits, also related to their riparian trees species, environment or biota, which potentially determine the fate of leaf litter.

Microorganisms, mainly bacteria and fungi, are key agents involved in litter breakdown and microbial decomposition of litter enhances the attractiveness of leaf detritus to detritivores that can degrade up to $50 \%$ of the annual litter input into lotic ecosystems (Hieber and Gessner, 2002). Additionally, in the bottom sediments of littoral zones, organic matter is degraded by both anaerobic and aerobic microorganisms and their composition and activity depend on the surrounding environment (Jonsson et al., 2001; Dzyuban, 2003). Among physicochemical characteristics, the availability of nutrients in surrounding media is mainly determining the development of different microbial groups forming the benthic community (Artigas et al., 2008).

In recent decades, native riparian vegetation has been modified by human activities, allowing the colonization by invasive tree species. Riparian ecosystems are highly vulnerable to exotic plant invasion (Hood and Naiman, 2000) due to their milder microclimatic conditions and the frequent natural and anthropogenic disturbances that create diverse niches to support invasive species (Chytrý et al., 2008). Shifts from native to exotic trees may alter the quality of leaf litter inputs into water body, thus causing effects on quantity and quality of nutrients (Molinero and Pozo, 2006), biotic communities (Weijers et al., 2009) and ecosystem functioning (Martinez et al., 2013). Several studies have been performed to examine invasive species effects on leaf decomposition rates in aquatic ecosystems by litterbags method, but still have found mixed effects (Swan et al., 2008; Marano et al., 2013; Serra et al., 2013). Variability in leaf litter decomposition rates in aquatic systems may be linked to the direct or indirect effect of leaf litter on the changes of benthic communities composition and activity (Bärlocher and Graça, 2002; Medina-Villar et al., 2015), that highlights the importance of specific studies in order to understand the effects of invasions on ecosystem functioning (Fargen et al., 2015).
Boxelder maple (Acer negundo L.) is an invasive plant of Lithuanian and as inspiring a potential threat to the stability of local ecosystems is controlled by the legal regulation documents of the State Plant Protection Service. A. negundo has become commonly distributed after its escape from cultivation during the 1930 s and has been included in the list of invasive and annulled species since 2004 (Gudžinskas et al., 2014). This species was deliberately introduced to Lithuania from North America and it has become wide spread, because it develops deep roots, sprout stumps, and prefers to grow in moist soils, but also tolerates drought. Due to the fact that the seeds of $A$. negundo are easily transported by water flow, it prolifically colonizes riverside communities containing black alder (Alnus glutinosa (L.) Gaertn.) (Gudžinskas et al., 2014).

Previously, we have investigated ecotoxicological effects of $A$. negundo and $A$. glutinosa leaf litter leachates obtained in laboratory experiments during 90-day decomposition of leaves under microaerobic/anaerobic (Krevš et al., 2013) and aerobic conditions (Manusadžianas et al., 2014). Besides temporal and species-dependent differences in toxicity to algae and invertebrates, it has been found that $A$. negundo leaves lose biomass more rapidly and release more nutrients during decomposition, than those of A. glutinosa.

Because of the tight coupling between riparian and aquatic habitats, we hypothesized that intensive spread of invasive species along the shoreline of the Neris River could alter the development of benthic microorganisms and organic matter mineralization in the littoral zone of the river. Taking into account a fast decomposition of $A$. negundo leaf litter observed under laboratory experiments, we expected a higher benthic microbial densities and, consequently, higher rates of mineralization processes in bottom sediments of the A. negundo litter accumulation zone than those in the zone nearby native trees. To test our hypothesis, physicochemical parameters, densities of microbial heterothrophs (bacteria and fungi) and activity of benthic community (expressed as the rate of organic carbon mineralization and sulfate reduction) were investigated in the bottom sediments of three different littoral sites of the river: one site was close by riparian $A$. negundo, another close by native trees (mostly A. glutinosa) location and a third zone was near the shore without riparian vegetation, respectively. Leaf litter was accumulated in littoral sediments of the first two sites.

\section{Study area and methods}

\subsection{Study area and sampling strategy}

The Neris is the largest tributary of the River Neman, and it is the second longest river in Lithuania. Its watercourse is $511 \mathrm{~km}$ : for $276 \mathrm{~km}$ the river runs through Belarus and for $235 \mathrm{~km}$ it flows through Lithuania including the capital Vilnius, and becomes a tributary of the River Neman in Kaunas. The Neris River basin surface is 2\% lakes, $14 \%$ swamps and 27\% forest (Encyclopedia of Lithuania, 2008). 
Due to the forested and laky basin, the water level is stable during the summer and rises only with the spring thaw. Neris is located in the temperate zone and its mean annual water temperature varies from $3{ }^{\circ} \mathrm{C}$ in January to $22^{\circ} \mathrm{C}$ in August (Galvonaite et al., 2007). In native riparian areas of the River Neris, deciduous tree communities prevail, and since the eighth decade of the 20th century, A. negundo has rapidly distributed along shoreline of the river (Straigyte et al., 2015).

The samples were collected in the River Neris segment of Vilnius vicinity $\left(54^{\circ} 44^{\prime} 25^{\prime \prime} \mathrm{N}, 25^{\circ} 17^{\prime} 55^{\prime \prime} \mathrm{E}\right)$. Three sampling sites in the narrow strip of the littoral zone with slow water flow were chosen for the study in the spring-autumn period (26-28 March, 31 July to 2 August and 16-18 October) 20132014. One of them (the A. negundo leaf litter accumulation zone) was located in the littoral part of the river where the bank was invaded by $A$. negundo, whose branches were hanging low over the water. Other site (the A. glutinosa leaf litter accumulation zone) was close by riparian native forest composed mainly of $A$. glutinosa. Bottom sediments of these littoral sites were covered by leaf litter, especially in the autumn-spring period. A third area of the littoral zone (the zone without leaf litter) was located along riverside with no trees growing on the bank. Sampling sites spacing downstream between $A$. negundo and the zone without leaf litter was approximately $1 \mathrm{~km}$, while between the zone without leaf litter and A. glutinosa zones about $1.5 \mathrm{~km}$. Each site had a surface area of about $2 \mathrm{~m}$ length and $0.5-0.7 \mathrm{~m}$ width from the river bank. These sites did not have macrophyte and were always in contact with water. Physicochemical $\left(T, \mathrm{pH}, \mathrm{O}_{2}, N_{t}, P_{t}, C_{\text {org }}, \mathrm{S} /\right.$ $\mathrm{SO}_{4}{ }^{2-}, \mathrm{H}_{2} \mathrm{~S}+\mathrm{HS}^{-}$) parameters, benthic heterothrophs (bacterial and fungal abundance) and the rates of sulfate reduction and organic carbon mineralization were studied in bottom sediments of these littoral sites at water depth of about 15$20 \mathrm{~cm}$. Samples were collected from a surface layer of bottom sediments $(0-5 \mathrm{~cm})$, using a metal tube sampler. Triplicate sediment samples were taken at each site for analysis. Samples for microbiological analyses were transported to the laboratory in sterile glass containers and examined immediately. Samples for chemical analyses were placed in plastic vials and transported to a certified analytical laboratory in insulated cooler. In situ the water temperature, dissolved oxygen concentration and $\mathrm{pH}$ were also measured at each sampling site. For microbial characteristics of decaying leaf litter, $A$. negundo and $A$. glutinosa leaves were collected from bottom sediments in the research sites two times: in March and October. At the laboratory, 20-30 leaves from each site was rinsed with deionized water to remove sediments and cut into disks of $10 \mathrm{~mm}$ diameter for further quantification of fungal and bacterial parameters.

\subsection{Physicochemical analysis}

Water temperature and $\mathrm{pH}$ were measured using a portable universal MultiLine f/Set-3 meter (WTW). Dissolved oxygen concentration was determined with oxygen meter (Eutech Instruments). Nutrient and sulfate analyses were performed in a certified analytical laboratory (JSC Water Investigations, Vilnius, Lithuania) in accordance with standard methods (ISO 6878; ISO 11905-1; ISO 8245; ISO 10304). Hydrogen sulfide was determined according to the method described by Volkov and Zhabina (1980).

\subsection{Microbial analysis}

For the investigation of benthic bacteria (total number, heterotrophic and cellulose-degrading bacteria), $1 \mathrm{~g}$ sediments were placed in flasks with $100 \mathrm{~mL}$ of autoclave sterilized water and sonicated in bath (Kraintek, Slovakia) for 4 min at $38 \mathrm{kHz}$ and then were extracted on a rotary shaker (Certomat ${ }^{\circledR}$ UHK50 ) with shaking (200 rpm) for 15-20 min. For bacterial (total number and heterotrophic bacteria) evaluation of decaying leaf litter, 15 leaf discs were placed in tubes with $5 \mathrm{~mL}$ of autoclaved water and sonicated in bath for $2+2 \mathrm{~min}$ at $38 \mathrm{kHz}$ (Artigas et al., 2008). The total number of bacteria were estimated by epifluorescence microscopy after 4',6-diamidino2-phenylindole (DAPI) staining on $0.2 \mu \mathrm{m}$ black filters (Millipore, Bedford, MA) (Porter and Feig, 1980). At least 200 bacterial cells in 20 fields were counted at 1000 magnification using epifluorescence microscope Nikon Eclipse (Japan). Heterotrophic bacteria were incubated on $10 \times$ diluted agar nutrient medium at $22^{\circ} \mathrm{C}$ for $120 \mathrm{~h}$ (Kuznetsov and Dubinina, 1989). Cellulose-degrading bacteria (CDB) were incubated on solid Hetchinson medium with $1 \%$ $\mathrm{CMC}$ at $22^{\circ} \mathrm{C}$ for two weeks. For the recognition of $\mathrm{CDB}$ colonies, $5 \mathrm{~mL}$ of $0.1 \%$ Congo red and $5 \mathrm{M} \mathrm{NaCl}$ were used in each plate (Kluepfel, 1988). To account for sulfate reducing bacteria (SRB) from surface layer of bottom sediment samples, they were inoculated into lactate-supplemented Postgate medium (Postgate, 1984).

The abundance of benthic terrestrial fungi was estimated after 7 days of cultivation on malt extract agar at constant $15^{\circ} \mathrm{C}$ in darkness. For fungal analyses of decaying leaf litter, a set of 20 leaf discs were placed in Erlenmeyer flasks containing $100 \mathrm{~mL}$ filtrated water and incubated on rotary shaker (Certomat ${ }^{(B)}$ UHK-50) with gentle shaking (75 rpm) for three days at $15^{\circ} \mathrm{C}$ (Gulis and Suberkropp, 2006). After incubation, part of the conidial suspension was used for the evaluation of terrestrial fungi abundance and directly plated on nutrient media. To estimate aquatic fungi abundance, $50 \mathrm{~mL}$ of the preserved conidia suspension was filtrated through $8 \mu \mathrm{m}$ membrane filter (Millipore), stained with $0.01 \%$ cotton blue in lactophenol and examined using a light microscope (PZO, Warszawa). One hundred microscopic fields were scanned per filter to count and identify conidia. For fungi and bacteria study, each of the three independent samples of every research site was analyzed in two sub-replicates. Microbial abundance was calculated per gram of dry weight sediments and expressed as a number of cells or colonies forming units (CFU)/g of DW sediments. The abundance of bacteria and fungi on leaf litter was evaluated in mg of dry leaf weight.

The carbon mineralization rate in bottom sediments was determined on the basis of respiratory activity of benthic aerobic and anaerobic community and measured from the amounts of consumed oxygen and released inorganic carbon in hermetically sealed stratometric tubes with a silt core and near bottom water (Kuznetsov and Dubinina, 1989). Percentage contribution of aerobic and anaerobic processes to carbon mineralization was evaluated after calculating the difference between total inorganic carbon emission and emission by aerobic respiration. For the evaluation of inorganic carbon emission by aerobic respiration, the values of consumed oxygen were converted to carbon by factor 0.44 (Kuznetsov and Dubinina, 1989). The sulfate reduction rate was 
ascertained using a Na${ }^{35} \mathrm{SO}_{4}$ tracer technique (Sorokin, 1999). Bottom sediment samples ( $0-5 \mathrm{~cm}$ deep) were placed in $20 \mathrm{~mL}$ glass tubes and hermetically sealed with rubber stoppers. A $0.1 \mathrm{~mL} \mathrm{Na}_{2}{ }^{35} \mathrm{SO}_{4}$ solution (Amersham Pharmacia Biotech) of at least $2-3 \times 10^{6} \mathrm{imp} / \mathrm{min}$ radioactivity was injected into the samples by syringe with long needle. Glass tubes with bottom sediment samples were stored in dark bags placed in hermetic impact resistant thermos bottles filled with bottom water. Thermos bottles were submerged near the shoreline of the river study site and incubated for $24 \mathrm{~h}$. The subsequent procedures were carried out in the laboratory. After the chemical treatment of samples, filters $(0.2 \mu \mathrm{m}$, Millipore $)$ were placed in vials containing $5 \mathrm{~mL}$ of scintillation cocktail Opti Phase Hi Safe 3 (Wallac Scintillation Products). Radioactivity was determined using a liquid scintillation counter.

\subsection{Statistical analysis}

Analysis of variance (ANOVA) was used to test for differences between three habitats in terms of chemical compound, microbial numbers and carbon mineralization rate. Tukey test was used to determine where the differences occurred $(p \leq 0.05)$. Data were log-transformed before statistical analysis. The similarity of fungal assemblages in the bottom sediments and on leaf litter was analysed by Sorenson's index (SI). The similarity is considered to be low $(<39 \%)$, moderate $(40-49 \%)$, high $(50-59 \%)$ and very high ( $>60 \%$ ) (Magurran, 1988). Pearson's correlation analysis was used to examine the relationship among biotic parameters, and between biotic and abiotic parameters. The statistical analysis was carried out using the software PASW Statistics 18.0 (Predictive Analytics Software, IBM).

\section{Results}

\subsection{Environmental conditions}

Near bottom water temperature, $\mathrm{pH}$ values and oxidative conditions determined in different littoral zones of the river were similar and varied only seasonally. Water temperature was moderate and increased from $8 \pm 1^{\circ} \mathrm{C}$ in March to $22 \pm 2{ }^{\circ} \mathrm{C}$ in July and decreased to $11 \pm 1{ }^{\circ} \mathrm{C}$ in October. The highest dissolved oxygen concentration was detected in October and March and ranged between 9.6 and $10.7 \mathrm{mg} / \mathrm{L}$. In midsummer its values decreased to $7.8-8.1 \mathrm{mg} / \mathrm{L}$. The $\mathrm{pH}$ value of water was weakly alkaline and ranged between 7.6 and 8.2.

The shoreline area of $A$. negundo habitat was swampy, without grass cover. The upper layer of sediments in littoral part covered by silt. Near native trees, mostly A. glutinosa habitat, bottom sediments of littoral part of the river was composed of grey sand mixed with silt impurities. Sandy gravel without biomass residue in the bottom sediments was found in open without leaf litter littoral part of the river. The values of chemical parameters were always the lowest in the sediments of the zone without leaf litter (Tab. 1). Content of nutrients in the littoral sediments differed between invasive and native trees leaf litter accumulation sites, while not always significantly. In October, $N_{t}$ and $C_{\text {org }}$ concentration was higher in $A$. negundo and in contrast, $P_{t}$ content was larger in the sediments of the native tree leaf litter accumulation zone. Also, bottom sediments showed differences in the $\mathrm{C} / \mathrm{N}$ ratio among sites (Tab. 1). The amount of hydrogen sulfide was always higher in A. negundo leaf litter accumulation zone than in A. glutinosa zone and in sulfate values, with the exception of October, were significant differences between both littoral sites.

\subsection{Benthic bacteria and fungi}

The lowest total benthic bacterial number was detected in March and the highest values were in October (Tab. 2). In the sediments of leaf litter accumulation zone, bacterial abundance was an average 1.5-2 times higher than that in sediments without leaf litter. In March, significant increase in the number of benthic bacteria was observed in A. negundo leaf litter accumulation zone comparing to the site with native tree leaf litter, while in July and October the differences in their number were not significant. Sulfate reducing bacteria number varied between $10^{3}$ and $10^{6} \mathrm{CFU} / \mathrm{dm}^{3}$ and was similar in the littoral sediments of $A$. negundo and native tree leaf litter accumulation zones. In the bottom sediments of zone without leaf litter their number was 100-1000 times lower than in tree leaf litter accumulation areas.

In contrast to bacteria, the highest abundance of terrestrial fungi in bottom sediments was detected in March and reached their maximum values in $A$. negundo leaf accumulation zone (Tab. 2). High similarity of fungal composition was determined in the bottom sediments of three littoral sites (71-92\%). However, dominant fungi assemblages differed between tree leaf litter accumulation areas (Tab. 3). Fungi genera Penicillium prevailed in the sediments of $A$. negundo leaf accumulation zone. In the bottom sediments of $A$. glutinosa leaf litter accumulation zone, in March and October the assemblages of Acremonium, Penicillium prevailed, while in midsummer most abundant fungi were of the genera Aspergillus and Mucor.

\subsection{Bacteria and fungi on decaying leaf litter in the bottom sediments of littoral sites}

The total bacterial abundance and heterotrophic bacteria colony number for study period were higher on $A$. negundo than on $A$. glutinosa leaf litter and insignificant greater amount of terrestrial fungi was determined on $A$. negundo leaf litter as well (Fig. 1). As for aquatic fungi, in October, during the accumulation of recently fallen leaves in the littoral part of the river, their sporulation rate was 14 times higher on $A$. negundo leaf litter than on A. glutinosa. In March, on the contrary, the more extensive colonization occurred on A. glutinosa leaf litter which was poorly disintegrated from the last fall. The similarity of fungi assemblages on leaves was low (27-30\%) and the composition of dominant fungi differed between both leaf species (Tab. 4).

\subsection{Organic carbon mineralization processes}

According to the rates of inorganic carbon emission from bottom sediments into the water, the benthic organisms were most active in October, when the total (aerobic and anaerobic) community respiratory activity (expressed as the rate of 
A. Krevš and A. Kučinskienė: Knowl. Manag. Aquat. Ecosyst. 2017, 418, 26

Table 1. Chemical parameters of bottom sediments in the littoral sites of the River Neris, 2013-2014 (mean values \pm SD). Different letters in a row indicate significant differences among sites for each parameter (ANOVA test with Tukey HSD, $p \leq 0.05$ ).

\begin{tabular}{|c|c|c|c|c|c|c|}
\hline \multirow[t]{2}{*}{ Leaf litter accumulation zones } & \multicolumn{6}{|c|}{ Parameters } \\
\hline & $N_{t}, \%$ & $P_{t}, \%$ & $C_{\text {org }}, \%$ & $\mathrm{H}_{2} \mathrm{~S}+\mathrm{HS}^{-}, \mathrm{mg} / \mathrm{dm}^{3}$ & $\mathrm{~S} / \mathrm{SO}_{4}{ }^{2-}, \mathrm{mg} / \mathrm{dm}^{3}$ & $\mathrm{C} / \mathrm{N}$ \\
\hline \multicolumn{7}{|l|}{ 26-28 March } \\
\hline A. negundo & - & - & $7.2 \pm 0.3^{\mathrm{a}}$ & $144 \pm 11^{\mathrm{a}}$ & $23.0 \pm 1.5^{\mathrm{a}}$ & - \\
\hline A. glutinosa & - & - & $6.9 \pm 0.1^{\mathrm{ab}}$ & $120 \pm 8^{\mathrm{b}}$ & $20.5 \pm 1.3^{\mathrm{b}}$ & - \\
\hline Zone without leaf litter & - & - & $2.9 \pm 0.2^{\mathrm{c}}$ & $44 \pm 3^{\mathrm{c}}$ & $15.3 \pm 0.9^{\mathrm{c}}$ & - \\
\hline \multicolumn{7}{|l|}{31 July-2 August } \\
\hline A. negundo & $0.10 \pm 0.01^{\mathrm{a}}$ & $0.025 \pm 0.002^{\mathrm{a}}$ & $5.9 \pm 1.7^{\mathrm{a}}$ & $265 \pm 18^{\mathrm{a}}$ & $26.1 \pm 1.4^{\mathrm{a}}$ & $58 \pm 11^{\mathrm{b}}$ \\
\hline A. glutinosa & $0.07 \pm 0.01^{\mathrm{ab}}$ & $0.024 \pm 0.002^{\mathrm{ab}}$ & $7.8 \pm 0.8^{\mathrm{b}}$ & $218 \pm 11^{\mathrm{b}}$ & $23.2 \pm 1.3^{\mathrm{b}}$ & $111 \pm 5^{\mathrm{a}}$ \\
\hline Zone without leaf litter & $0.04 \pm 0.02^{\mathrm{c}}$ & $0.016 \pm 0.00^{\mathrm{c}}$ & $0.7 \pm 0.1^{\mathrm{c}}$ & $150 \pm 18^{\mathrm{c}}$ & $16.7 \pm 1.0^{\mathrm{c}}$ & $22 \pm 9^{c}$ \\
\hline \multicolumn{7}{|l|}{ 16-18 October } \\
\hline A. negundo & $0.24 \pm 0.02^{\mathrm{a}}$ & $0.035 \pm 0.003^{\mathrm{b}}$ & $9.0 \pm 0.5^{\mathrm{a}}$ & $269 \pm 11^{\mathrm{a}}$ & $38.4 \pm 1.4^{\mathrm{a}}$ & $38 \pm 2^{\mathrm{b}}$ \\
\hline A. glutinosa & $0.10 \pm 0.02^{\mathrm{b}}$ & $0.052 \pm 0.003^{\mathrm{a}}$ & $6.9 \pm 0.2^{\mathrm{b}}$ & $220 \pm 11^{\mathrm{b}}$ & $37.4 \pm 1.1^{\mathrm{ab}}$ & $72 \pm 13^{\mathrm{a}}$ \\
\hline Zone without leaf litter & $0.06 \pm 0.01^{\mathrm{c}}$ & $0.024 \pm 0.005^{\mathrm{c}}$ & $1.5 \pm 0.4^{\mathrm{c}}$ & $92 \pm 23^{c}$ & $14.2 \pm 2.1^{\mathrm{c}}$ & $25 \pm 3^{c}$ \\
\hline
\end{tabular}

- , not determined.

Table 2. Microbial abundance in the bottom sediments of littoral sites of the River Neris, 2013-2014 (mean values \pm SD). TNB - total number of bacteria; HB - heterotrophic bacteria; CDB - cellulose decomposing bacteria; SRB - sulfate reducing bacteria; TFung - terrestrial fungi. Different letters in a row indicate significant differences among sites for each parameter (ANOVA test with Tukey HSD, $p \leq 0.05$ ).

\begin{tabular}{|c|c|c|c|c|c|}
\hline \multirow[t]{2}{*}{ Leaf accumulation zone } & \multicolumn{5}{|c|}{ Microorganisms } \\
\hline & $\mathrm{TNB}, 10^{6} / \mathrm{g}$ & $\mathrm{HB}, 10^{3} \mathrm{CFU} / \mathrm{g}$ & $\mathrm{CDB}, 10^{3} \mathrm{CFU} / \mathrm{g}$ & $\mathrm{SRB}, \mathrm{CFU} / \mathrm{dm}^{3}$ & $\overline{\text { TFung, CFU/g }}$ \\
\hline \multicolumn{6}{|l|}{ 26-28 March } \\
\hline A. negundo & $158.0 \pm 2.4^{\mathrm{a}}$ & $20.1 \pm 2.2^{\mathrm{a}}$ & $8.7 \pm 1.8^{\mathrm{a}}$ & $10^{5}$ & $9700 \pm 818^{\mathrm{a}}$ \\
\hline A. glutinosa & $136.0 \pm 7.0^{\mathrm{b}}$ & $12.5 \pm 0.5^{\mathrm{b}}$ & $7.0 \pm 0.5^{\mathrm{ab}}$ & $10^{5}$ & $5933 \pm 404^{b}$ \\
\hline Zone without leaf litter & $96.5 \pm 8.7^{\mathrm{c}}$ & $6.5 \pm 1.0^{\mathrm{c}}$ & $2.9 \pm 0.3^{\mathrm{c}}$ & $10^{3}$ & $570 \pm 61^{\mathrm{c}}$ \\
\hline \multicolumn{6}{|l|}{31 July-2 August } \\
\hline A. negundo & $182.5 \pm 30.7^{\mathrm{a}}$ & $218.0 \pm 10.3^{\mathrm{a}}$ & $69.5 \pm 26.0^{\mathrm{a}}$ & $10^{6}$ & $1753 \pm 129^{\mathrm{a}}$ \\
\hline A. glutinosa & $187.2 \pm 23.3^{\mathrm{ab}}$ & $204.2 \pm 16.1^{\mathrm{ab}}$ & $62.2 \pm 34.7^{\mathrm{a}}$ & $10^{5}-10^{6}$ & $420 \pm 79^{b}$ \\
\hline Zone without leaf litter & $126.3 \pm 21.1^{\mathrm{c}}$ & $133.7 \pm 21.1^{\mathrm{c}}$ & $36.0 \pm 19.0^{\mathrm{a}}$ & $10^{3}$ & $180 \pm 27^{\mathrm{c}}$ \\
\hline \multicolumn{6}{|l|}{ 16-17 October } \\
\hline A. negundo & $217.8 \pm 29.0^{\mathrm{a}}$ & $133.0 \pm 13.5^{\mathrm{a}}$ & $46.0 \pm 28.0^{\mathrm{a}}$ & $10^{6}$ & $1253 \pm 115^{\mathrm{a}}$ \\
\hline A. glutinosa & $191.6 \pm 65.1^{\mathrm{ab}}$ & $114.5 \pm 7.0^{\mathrm{b}}$ & $30.0 \pm 16.0^{\mathrm{ab}}$ & $10^{5}-10^{6}$ & $1587 \pm 247^{\mathrm{ab}}$ \\
\hline Zone without leaf litter & $156.1 \pm 12.2^{\mathrm{bc}}$ & $88.0 \pm 27.0^{\mathrm{bc}}$ & $13.2 \pm 6.2^{\mathrm{c}}$ & $10^{3}$ & $153 \pm 38^{\mathrm{c}}$ \\
\hline
\end{tabular}

organic carbon mineralization) varied from $1560 \pm 54$ to $2520 \pm 509 \mathrm{mg} \mathrm{C} / \mathrm{m}^{2} \mathrm{~d}^{-1}$ in the zone without leaf litter and A. negundo leaf litter littoral areas, respectively (Fig. 2A). The parallel measurements of the oxygen uptake rate showed that aerobic organic carbon mineralization was most intensive in March (Fig. 2B), however throughout the study period anaerobic processes predominated in organic matter mineralization. Anaerobic $C_{\text {org }}$ mineralization was more intensive in the sediments of $A$. negundo leaf litter accumulation zone and made up on average $90 \pm 5 \%$ versus $75 \pm 7 \%$ in the littoral area with A. glutinosa leaf litter and $64 \pm 5 \%$ of the total (aerobic+anaerobic) mineralization in the zone without leaf litter. However A. glutinosa leaf litter accumulation zone was distinguished by the higher respiration activity of aerobic community and differences in oxygen consumption rate were observed between tree leaf litter accumulation areas during the whole study period (Fig. 2B).

In different periods of observation, the rates of sulfate reduction (SR) - the terminal pathway of organic carbon mineralization in bottom sediments were $0.26-0.87 \mathrm{mg} \mathrm{S}^{2-}$ / $\mathrm{dm}^{3} \mathrm{~d}^{-1}$, respectively, in A. negundo and A. glutinosa leaf litter accumulation zones and $0.09-0.2 \mathrm{mg} \mathrm{S}^{2-} / \mathrm{dm}^{3} \mathrm{~d}^{-1}-$ in the zone without leaf litter (Fig. 2C). The highest SR values were observed in $A$. negundo and native tree leaf litter accumulation 
Table 3. Dominant fungi in the bottom sediments of invasive and native trees leaf litter accumulation zones and littoral zone without leaf litter, 2014 (\% of the total fungi number).

\begin{tabular}{|c|c|c|c|}
\hline \multirow[t]{2}{*}{ Date } & \multicolumn{2}{|c|}{ Leaf litter accumulation zones } & \multirow[t]{2}{*}{ Zone without leaf litter } \\
\hline & A. negundo & A. glutinosa & \\
\hline \multirow[t]{5}{*}{ March } & Penicillum (65\%) & Penicillum (39\%) & Penicillum (37\%) \\
\hline & Acremonium (14\%) & Acremonium (27\%) & Phoma (24\%) \\
\hline & Phoma (11\%) & Trichoderma $(9 \%)$ & Mucor $(13 \%)$ \\
\hline & & Cladosporium (7\%) & Cladosporium (12\%) \\
\hline & & & Trichoderma (11\%) \\
\hline \multirow[t]{4}{*}{ July-August } & Penicillum (88\%) & Aspergillus (26\%) & Aspergillus (39\%) \\
\hline & & Mucor $(22 \%)$ & Mucor $(22 \%)$ \\
\hline & & Penicillum (19\%) & Acremonium (16\%) \\
\hline & & Alternaria $(14 \%)$ & Alternaria $(10 \%)$ \\
\hline \multirow[t]{3}{*}{ October } & Penicillum (61\%) & Acremonium (57\%) & Acremonium (55\%) \\
\hline & Trichoderma $(19 \%)$ & Penicillum (19\%) & Penicillum (19\%) \\
\hline & & Mucor $(13 \%)$ & Fusarium (17\%) \\
\hline
\end{tabular}

zones in July and October and ranged within $0.76 \pm 0.05$ $0.87 \pm 0.04$ and $0.62 \pm 0.05-0.65 \pm 0.04 \mathrm{mg} \mathrm{S}^{2-} / \mathrm{dm}^{3} \mathrm{~d}^{-1}$ respectively, while in the zone without leaf litter this process was twice less. SR rates were significantly higher in sediments of A. negundo than of $A$. glutinosa leaf litter accumulation sites.

Direct correlation was observed between SR rate and concentration of sulfates and hydrogen sulfide in tree litter accumulation zones (Tab. 5) and no correlation was found between this process and the amount of SRB. A direct relationship was detected between total benthic bacterial numbers and rate of organic carbon mineralization (MR) for all study areas. There was no statistically significant dependence of MR and SR on the total $C_{\text {org }}$ content in the sediments and temperature. In the sediments of leaves accumulation sites $\mathrm{C} / \mathrm{N}$ ratio correlated negatively with MR and SR.

\section{Discussion}

The leaf fall of $A$. negundo and native $A$. glutinosa occur in different ways: $A$. glutinosa leaves fall gradually within approximately one-two months. A. negundo leaves fall almost at once during early autumnal frosts, forming a thick layer of leaf litter (Manusadžianas et al., 2014), which creates particularly favourable conditions for microbial decomposition. During this study, we found that in spring in the littoral zone of the river A. negundo leaves were very soft and their tissue was high macerated in contrast to more recalcitrant species of $A$. glutinosa leaves which were quite tough and weakly disintegrated. More rapid microbial decomposition of $A$. negundo leaves compared to A. glutinosa has also been found in laboratory experiments under various oxygen conditions (Krevš et al., 2013; Manusadžianas et al., 2014). These results concur with the findings of other studies indicating that many alien trees have more rapidly decomposing leaf litter than the native species they replace (e.g., Harner et al., 2009; Janušauskaitė and Straigytė, 2011; Jaeger et al., 2013). Despite the similar initial nutrient content between $A$. negundo and A. glutinosa leaves (Manusadžianas et al., 2014), the higher biodegradability of $A$. negundo leaves could be due to other leaf characteristics such as, e.g., toughness, content of humic substances or secondary metabolites (Moretti et al., 2007) that influence the consumption rate of leaf litter by consumers. Leaf quality influences the abundance, composition and activity of microorganisms that participate in litter decomposition and changes when native species are replaced by invasive ones (Casas et al., 2013). In the present study, the amount of bacteria and fungi was greater on $A$. negundo leaf litter decomposing in the littoral area indirectly indicating that leaves of this invasive species was a better nutrient source for microorganisms than of $A$. glutinosa. After leaf fall, the colonization of $A$. negundo leaves by aquatic fungi was also more extensive than that of A. glutinosa. Because fungi species vary in enzymatic activity (Rodrigues and Graça, 1997), low similarity of dominating species on the leaves of both tree types could induce differences in their litter decomposition rates.

Invasion of riparian forests can alter nutrient dynamics of ecosystems through increase in $\mathrm{N}$ inputs and decomposition of $\mathrm{N}$-rich organic matter within ecosystems (MacKenzie et al., 2013) with faster release of nutrients (Allison and Vitousek, 2004). This is in agreement with laboratory experiments showing that higher content of nutrients, mostly nitrogen and labile organic matter, was found in the medium with decomposing A. negundo leaves than with A. glutinosa (Krevš et al., 2013; Manusadžianas et al., 2014). These differences can suggest a stronger impact of $A$. negundo leaves on the chemical parameters of natural habitats. To some extent, the findings in the littoral zone of the River Neris endorse these general assumptions, since the nutrient content in the sediments increased in autumn after leaf fall, and that a little higher $N_{t}$ and $C_{\text {org }}$ concentration was recorded in the A. negundo leaf litter accumulation zone. Higher proportion of $\mathrm{N}$ in organic matter reflects the better nutrient availability of substrates for microbial mineralization 


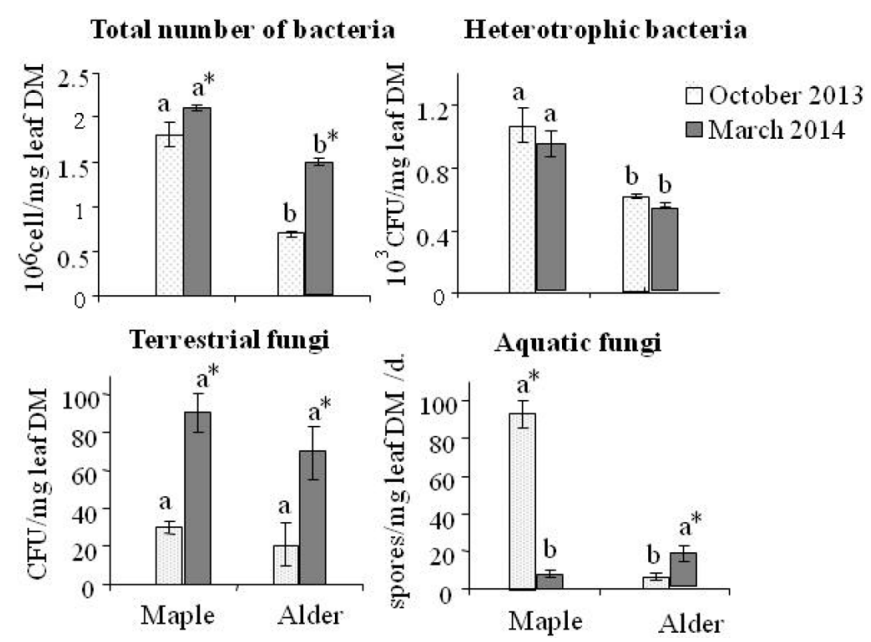

Fig. 1. Microbial densities on A. negundo (maple) and A. glutinosa (alder) leaf litter decomposing in the littoral zone of the River Neris. Different letters $(\mathrm{a}>\mathrm{b})$ indicate significant differences among leaf species obtained with Tukey test at $p \leq 0.05$. *Differences in the microbial number (significant higher number) on the same leaf species between sampling time.
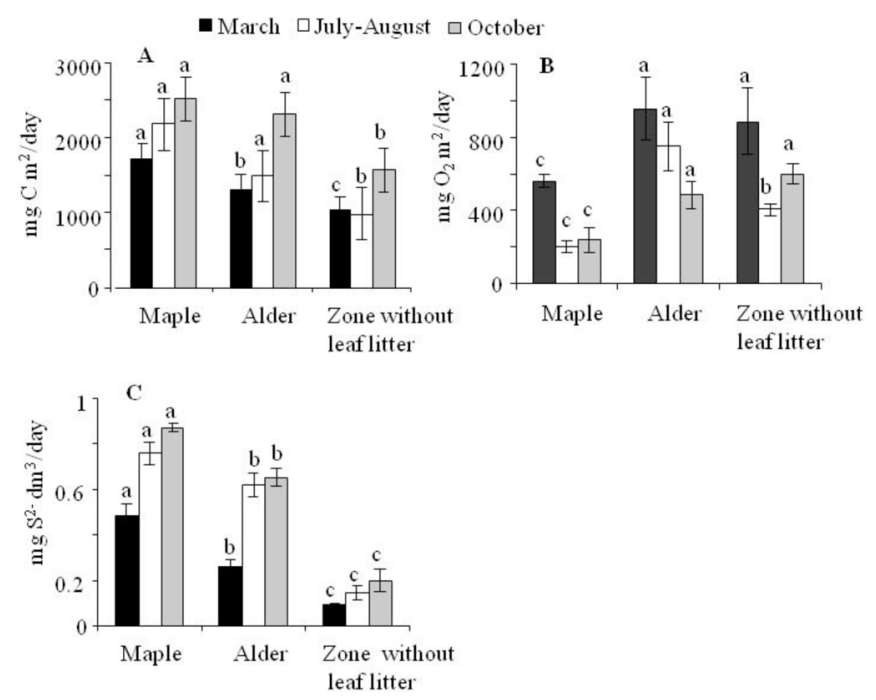

Fig. 2. The rate of inorganic carbon emission (A), oxygen consumption (B) and sulfate reduction (C) in the bottom sediments of $A$. negundo (maple), A. glutinosa (alder) leaf litter accumulation sites and littoral zone without leaf litter of the River Neris. Different letters $(\mathrm{a}>\mathrm{b}>\mathrm{c})$ indicate significant differences between parameters among sites (Tukey test at $p \leq 0.05$ ).

Table 4. Dominant aquatic fungi species on A. negundo and A. glutinosa leaf litter decomposing in the littoral zone of the River Neris (\% of the total production of conidia).

\begin{tabular}{lll}
\hline Date & Acer negundo & Alnus glutinosa \\
\hline October 2013 & Tetracladium marchalianum (53\%) & Tricladium angulatum $(56 \%)$ \\
& Flagellospora curvula $(36 \%)$ & Xylomyces sp. $(9 \%)$ \\
& & Alatospora acuminata $(6 \%)$ \\
& & F. curvula $(6 \%)$ \\
March 2014 & Anguillospora spp. $(37 \%)$ & A. acuminata $(22 \%)$ \\
& F. curvula $(19 \%)$ & Trinacrium sp. $(16 \%)$ \\
& Anguillomyces acadiensis $(15 \%)$ & Tetracladium sp. $(13 \%)$ \\
& Mirandium sp. $(11 \%)$ & Trifurcospora irregularis $(13 \%)$ \\
& Titaea complexa $(11 \%)$ & Camposporium spp. $(10 \%)$ \\
\hline
\end{tabular}

Table 5. Pearson correlation test between the rates of mineralization processes in the bottom sediments of littoral sites and environmental conditions (TR, SR, TNB stand for mineralization rate, sulfate reduction and total bacterial number, respectively).

\begin{tabular}{lcccr}
\hline Parameters & \multicolumn{2}{c}{ Leaf litter accumulation sites } & \multicolumn{2}{c}{ Zone without leaf litter } \\
\cline { 2 - 5 } & $\mathrm{TR}, \mathrm{mg} \mathrm{C} / \mathrm{m}^{2} \mathrm{~d}^{-1}$ & $\mathrm{SR}, \mathrm{mg} \mathrm{S}^{2-} / \mathrm{dm}^{3} \mathrm{~d}^{-1}$ & & $\mathrm{TR}, \mathrm{mg} \mathrm{S}^{2-} / \mathrm{dm}^{2} \mathrm{~d}^{-1} \mathrm{~d}^{-1}$ \\
\hline$T,{ }^{\circ} \mathrm{C}$ & 0.10 & 0.45 & 0.29 & 0.09 \\
$C_{\text {org }}, \%$ & 0.36 & 0.11 & 0.11 & 0.41 \\
$\mathrm{C} / \mathrm{N}$ & $-0.86^{* *}$ & $-0.81^{* *}$ & -0.11 & -0.08 \\
$\mathrm{~S} / \mathrm{SO}_{4}{ }^{2-}, \mathrm{mg} / \mathrm{dm}^{3}$ & $0.71^{* *}$ & $0.84^{* *}$ & -0.22 & 0.18 \\
$\mathrm{H}_{2} \mathrm{~S}+\mathrm{HS}^{-}, \mathrm{mg} / \mathrm{dm}^{3}$ & $0.61^{* *}$ & $0.91^{* *}$ & 0.30 & 0.44 \\
$\mathrm{TNB}, 10^{6} / \mathrm{g}$ & $0.75^{* *}$ & 0.40 & $0.54^{*}$ & 0.20 \\
\hline
\end{tabular}

$* p \leq 0.05$.

$* * p \leq 0.01$. 
(Mansson and Falkengren-Grerup, 2003). According to $\mathrm{C} / \mathrm{N}$ ratio, sediments with leaf litter of $A$. negundo had a higher content of available organic matter than sediments of $A$. glutinosa leaf accumulation site. As a result of mineralization and resuspension in water, in midsummer the amount of nutrients was approximately the same for both $A$. negundo and native tree leaf litter accumulation areas, but their content was always higher than in the sediments of littoral area without leaf litter. So, the features of $A$. negundo leaves fall with forming of a thick layer of leaf litter, the accumulation of available organic matter and its transformation products in sediments might be the reason of extension of swampy area that was observed along the shoreline of $A$. negundo mass growth.

In the bottom sediments of littoral zone, microorganism composition and activity primarily depend on the structure of organic matter and also on the surrounding environmental variables such as temperature, redox potential, and physical disturbance (Jonsson et al., 2001). In our study, the environmental conditions that affected the microbial densities and activity varied. As a result, heterotrophic and cellulosedecomposing bacterial colony numbers reached maximum in midsummer at the highest water temperature. In contrast to bacteria, the greatest abundance of benthic fungi was detected at the lowest water temperature. However, despite the seasonal variations, higher numbers of fungi and bacteria were observed in littoral sediments with $A$. negundo leaf litter than in native tree leaf litter accumulation zone that could be related to differences in organic matter availability. Based on microbial structure data we may expect that microbiological situation in littoral area will change if $A$. negundo continues to displace native species from the ecotones of the River Neris.

After leaf fall, enrichment of the bottom sediments with fresh organic matter favoured the activity of benthic communities. Additionally, microbial activity depended on the qualitative composition of organic matter rather than on the total OM content. This was supported by the absence of a statistically significant relationship between community respiration rate and total concentration of $C_{\text {org }}$ and by the presence of negative correlation between mineralization rates and $\mathrm{C} / \mathrm{N}$ ratio in the sediments of leaf litter accumulation sites. The highest rates of inorganic carbon emission from bottom sediments into the water were found in A. negundo leaf accumulation zone in October and were comparable to those for shallow low-running eutrophic lakes (Krevs and Kucinskiene, 2012). Despite the shallow depth and oxidative conditions in the near-bottom water $\left(\mathrm{O}_{2}>8 \mathrm{mg} / \mathrm{L}\right)$ due to accumulation of organic detritus, the anaerobic processes prevailed in organic carbon mineralization in leaf litter accumulation zones. Similar trends in organic carbon mineralization have been also observed in the sediments of shallow lakes and in the shallow areas of the lakes with a high content of organic matter (Kučinskienè and Krevš, 2006; Krevs and Kucinskiene, 2012). More active anaerobic bacteria and, in turn, intensive anaerobic organic carbon mineralization occurred in A. negundo leaf litter accumulation zone; however, A. glutinosa leaf litter site was distinguished by the higher activity of aerobic community.

Anaerobic conditions, sulfates and available OM are known to be the major factors that determine the activity of sulfate-reducing bacteria (SRB), which play a crucial role in the terminal anaerobic organic carbon mineralization, while temperature is only partially responsible for the seasonal SRB activity in aquatic ecosystems ( $\mathrm{Li}$ et al., 1996; Holmer and Storkholm, 2001). During the summer-autumn period in bottom sediments of leaf litter accumulation zones under sufficient sulfate concentration, the activity of sulfate reducing bacteria was promoted due to accumulation of labile organic matter and partly because of temperature. A higher abundance of heterotrophic bacteria determined in bottom sediments of leaf litter accumulation zone in its turn could produce a greater variety of substrates for sulfate reducing bacteria (Parkes et al., 1989) and intensify SR process. In litter accumulation zone, in spite of the oxidative conditions in the near-bottom water, the abundance and activity of SRB were similar to those in profundal zone of stratified lakes with anaerobic hypolimnion (Krevs and Kucinskiene, 2012). Changes in the structural composition of organic matter might have a stronger influence on the succession of SRB physiological groups and their activity than on their amount (Karnachuk et al., 2006). Similarly, in the present study, a direct relationship between the amount of SRB and SR intensity was not observed. The higher rates of SR in $A$. negundo than in A. glutinosa leaf litter accumulation sites indicated that organic substrate there was more available for the development of SRB. The end product of SR is hydrogen sulfide, a substance which is highly toxic for benthic fauna (Cook, 1992). Also, the highest concentration of hydrogen sulfide was recorded during midsummer-autumn in the bottom sediments of littoral site with $A$. negundo leaf litter.

Thus, our results have shown that on average during the study period the higher number of microorganisms and their community activity, with prevailing anaerobic processes, occurred in the littoral sediments of $A$. negundo leaf litter accumulation zone than in sediments of the river close by riparian native tree location. In shallow zones, anaerobic processes have negative consequences, because they promote the accumulation of fermentation products and other intermediate mineralization compounds (Kuznetsov et al., 1985) as well as benthic phosphorus release (Woszczyk et al., 2011), which, in its turn, may stimulate secondary eutrophication and littoral silting. On the other hand, increasing anaerobic sulfate reduction accelerates the growth of hydrogen sulfide concentration what in the future may have a negative impact on the quantitative and qualitative structure of benthic organisms. We think that more studies that focus on the effects of this alien riparian tree species on the littoral zone of freshwater systems are needed. These studies may be useful for predicting and minimizing the impact of invasive riparian vegetation on aquatic ecosystems.

Acknowledgements. We are very grateful to Dr. R. Mačkinaite for the help of fungal analysis and to Professor of Biology J. Trimble (Saint Francis University, USA) for the revision of the English language of this manuscript. This work was funded by the Grant No. LEK-12/2012 from the Research Council of Lithuania.

\section{References}

Allison SD, Vitousek P. 2004. Rapid nutrient cycling in leaf litter from invasive plants in Hawai'I. Oecologia 141: 612-619.

Artigas J, Romani A, Sabater S. 2008. Relating nutrient molar ratios of microbial attached communities to organic matter utilization in a forested stream. Fundam Appl Limnol 173: 255-264. 
Bärlocher F, Graça M. 2002. Exotic riparian vegetation lowers fungal diversity but not leaf decomposition in Portuguese streams. Freshw Biol 47: 1123-1135.

Casas JJ, Larrañaga A, Menéndez M, et al. 2013. Leaf litter decomposition of native and introduced tree species of contrasting quality in headwater streams: how does the regional setting matter? Sci Total Environ 458-460: 197-208.

Chytrý M, Maskell LC, Pino J, et al. 2008. Habitat invasions by alien plants: a quantitative comparison between Mediterranean, subcontinental and oceanic regions of Europe. J Appl Ecol 45: 448-458.

Cook R. 1992. Controls of sulfur cyclinging in small lakes. Interact Biogeochem Cycl Aquat Ecosyst 7: 211-223.

Dzyuban A. 2003. Bacteriobenthos of the upper Volga reservoirs as a characteristic of their environmental state. Water Res 30: 680-688.

Encyclopedia of Lithuania. 2008. Vilnius: Science Encyclopedia Publishing Institute.

Fargen C, Emery S, Carreiro M. 2015. Influence of Lonicera maackii invasion on leaf litter decomposition and macroinvertebrate communities in an Urban Stream. Nat Area J 35: 392-403.

Galvonaitė A, Misiunienė M, Valiukas D, Buitkuvienè MS. 2007. Lithuanian climate. Vilnius: Lithuanian Hydrometeorological Service, 180 p. (in Lithuanian).

Graça MAS, Canhoto C. 2006. Leaf litter processing in low order streams. Limnetica 25: 1-10.

Gudžinskas Z, Kazlauskas M, Pilāte D, et al. 2014. Invasive organisms in transboundary area of Lithuania and Latvia. BMK Publishers, pp. 19-20.

Gulis V, Suberkropp K. 2006. Fungi: biomass, production, and sporulation of aquatic hyphomycetes. In: Hauer FR, Lamberti GA, eds. Methods in stream ecology, 2nd ed. Amsterdam: Elsevier, pp. 311-325.

Harner M, Crenshaw C, Abelho M, Stursova M, Shah JJ, Sinsabaugh R. 2009. Decomposition of leaf litter from a native tree and an actinorhizal invasive riparian habitats. Ecol Appl 19: 1135-1146.

Hieber M, Gessner MO. 2002. Contribution of stream detrivores, fungi and bacteria to leaf breakdown based on biomass estimates. Ecology 83: 1026-1038.

Holmer M, Storkholm P. 2001. Sulphate reduction and sulphur cycling in lake sediments: a review. Freshw Biol 46: 431-451.

Hood WG, Naiman RJ. 2000. Vulnerability of riparian zones to invasion by exotic vascular plants. Plant Ecol 148: 105-114.

Jaeger H, Alencastro MJ, Kaupenjohann M, Kowarik I. 2013. Ecosystem changes in Galapagos highlands by the invasive tree Cinchona pubescens. Plant Soil 371: 629-640.

Janušauskaitè D, Straigyte L. 2011. Leaf litter decomposition differences between alien and native maple species. Balt For 17 (2): 189-196.

Jonsson A, Meili M, Bergström AK, Jansson M. 2001. Whole lake mineralization of allochthonous and autochthonous organic carbon in a large humic lake (Ortrasket, N. Sweden). Limnol Oceanogr 46: $1691-1700$

Karnachuk O, Pimenov N, Yusupov S, Frank Y, Puhakka Y, Ivanov M. 2006. Distribution, diversity and activity of sulfate reducing bacteria in the water column in Gek Gel Lake. Microbiology 75: 82-89.

Kluepfel D. 1988. Screening of prokaryotes for cellulose-and hemicellulose-degrading enzymes. In: Wood WA, Kellogg ST, eds. Methods in enzymology, vol. 160. London: Academic Press, pp. 181-185.

Krevs A, Kucinskiene A. 2012. Microbial decomposition of organic matter in the bottom sediments of small lakes of the urban landscape (Lithuania). Microbiology 81: 477-483.
Krevš A, Darginavičiené J, Jurkonienė S, et al. 2013. Ecotoxicological effects evoked in hydrophytes by leachates of invasive Acer negundo and autochthonous Alnus glutinosa fallen off leaves during their microbial decomposition. Environ Pollut 173: 75-84.

Kučinskienė A, Krevš A. 2006. Mineralization of organic matter in bottom sediments of the littoral zones of four Lithuanian lakes. Ekologija 1: 40-47.

Kuznetsov SI, Dubinina GA. 1989. Methods of investigation of aquatic microorganisms. Moskow: Nauka, 285 p. (in Russian).

Kuznetsov SI, Saralov AI, Nazina TN. 1985. Microbiological processes of turnover of carbon and nitrogen in lakes. Moscow: Nauka, 213 p. (in Russian).

Li JH, Takii S, Kotakemori R, Hayashi H. 1996. Sulfate reduction in profundal sediments in Lake Kizaki, Japan. Hydrobiologia 333: 201-208.

MacKenzie RA, Cormier N, Kinslow F, Wiegner TN, Strauch AM. 2013. Leaf-litter inputs from an invasive nitrogen-fixing tree influence organic-matter dynamics and nitrogen inputs in a Hawaiian river. Freshw Sci 32: 1036-1052.

Magurran AE. 1988. Ecological diversity and its measurement. London/Sydney: Springer.

Mansson KF, Falkengren-Grerup U. 2003. The effect of nitrogen deposition on nitrification, carbon and nitrogen mineralisation and litter $\mathrm{C} / \mathrm{N}$ rations in oak (Quercus robur L.) forests. For Ecol Manage 179: 455-467.

Manusadžianas L, Darginavičienè J, Gylytė B, et al. 2014. Ecotoxicity effects triggered in aquatic organisms by invasive Acer negundo and native Alnus glutinosa leaf leachates obtained in the process of aerobic decomposition. Sci Total Environ 496: 35-44.

Marano A, Saparrat M, Steciow M, et al. 2013. Comparative analysis of leaf-litter decomposition from the native Pouteria salicifolia and the exotic invasive Ligustrum lucidum in a lowland stream (Buenos Aires, Argentina). Fundam Appl Limnol 183: 297-307.

Martinez A, Larranaga A, Perez J, Descals E, Basaguren A, Pozo J. 2013. Effects of pine plantations on structural and functional attributes of forested streams. For Ecol Manage 310: 147-155.

Medina-Villar S, Alonso A, Vazquez de Aldana B, Perez-Corona E. 2015. Decomposition and biological colonization of native and exotic leaf litter in a Central Spain stream. Limnetica 34: 293-310.

Molinero J, Pozo J. 2006. Organic matter, nitrogen and phosphorus fluxes associated with leaf litter in two small streams with different riparian vegetation: a budget approach. Arch Hydrobiol 166: 363-385.

Moretti MS, Gonçalves JF, Callisto M. 2007. Leaf breakdown in two tropical streams: differences between single and mixed species packs. Limnologica 37: 250-258.

Parkes RJ, Gibson GR, Mueller-Harvey I, Buckingham W, Herbert RA. 1989. Determination of the substrates for sulphate-reducing bacteria within marine and estuarine sediments with different dates of sulphate reduction. J Gen Microbiol 135: 175-187.

Porter K, Feig YS. 1980. The use of DAPI for identifying and counting aquatic microflora. Limnol Oceanogr 25: 943-948.

Postgate JR. 1984. The sulfate reducing bacteria, 2nd ed. Cambridge Univ. Press, 208 p.

Rodrigues APL, Graça MAS. 1997. Enzymatic analysis of leaf decomposition in freshwater by selected aquatic hyphomycetes and terrestrial fungi. Sydowia 49: 160-173.

Serra MN, Albarino R, Diaz Villanueva V. 2013. Invasive Salix fragilis alters benthic invertebrate communities and litter decomposition in northern Patagonian streams. Hydrobiology 701: 173-188.

Sorokin J. 1999. Aquatic microbial ecology. Backhaus Publishers, $247 \mathrm{p}$. 
A. Krevš and A. Kučinskienė: Knowl. Manag. Aquat. Ecosyst. 2017, 418, 26

Straigyte L, Cekstere G, Laivins M, Marozas V. 2015. The spread, intensity and invasiveness of the Acer negundo in Riga and Kaunas. Dendrobiology 74: 157-168.

Swan CM, Healey B, Richardson DC. 2008. The role of native riparian tree species in decomposition of invasive tree of heaven (Ailanthus altissima) leaf litter in an urban stream. Ecoscience 15: 27-35.

Volkov II, Zhabina NN. 1980. Methods for determination of various sulfur compounds in marine sediments. Moscow: Nauka, 216 p. (in Russian).

Wallace J, Eggert S, Meyer J, Webster J. 1997. Multiple trophic levels of a forest stream linked to terrestrial litter inputs. Science 227: 102-104.
Weijers MJ, Janse JH, Alkemade R, Verhoeven TA. 2009. Quantifying the effect of catchment land use and water nutrient concentrations on freshwater river and stream biodiversity. Aquat Conserv 19: 104-112.

Weissteiner CJ, Bouraoui F, Aloe A. 2013. Reduction of nitrogen and phosphorus loads to European rivers by riparian buffer zones. Knowl Manag Aquat Ecosyst 408: 1-15.

Woszczyk M, Bechtel A, Cieslinski R. 2011. Interactions between microbial degradation of sedimentary organic matter and lake hydrodynamics in shallow water bodies: insights from Lake Sarbsko (northern Poland). J Limnol 70: 293-304.

Cite this article as: Krevš A, Kučinskienė A. 2017. Influence of invasive Acer negundo leaf litter on benthic microbial abundance and activity in the littoral zone of a temperate river in Lithuania. Knowl. Manag. Aquat. Ecosyst., 418, 26. 